\title{
PELAYANAN ADVOKASI PENGHASIL PANGAN SKALA KECIL OLEH OXFAM INDONESIA
}

\author{
Oleh: \\ Amelia Febriani Putri, Santoso T. Raharjo, \& Maulana Irfan \\ Email:
}

febrianiamel@gmail.com; santoso.tri.raharjo@unpad.ac.id; sangirfan@gmail.com

\begin{abstract}
ABSTRAK
Indonesia adalah negara agraris dengan luas daratan kurang lebih 190,9 juta ha. Dengan adanya pertambahan jumlah penduduk yang terus meningkat, dibarengi dengan pertumbuhan ekonomi dan industri, menimbulkan konversi lahan pertanian. Masalah yang dihadapi oleh penghasil pangan skala kecil saat ini berupa konversi lahan pertanian menjadi alih fungsi untuk kepentingan non-pertanian. Ketidakberdayaan para penghasil pangan skala kecil untuk menjaga lahan pertanian yang mereka miliki menjadi penyebab terjadinya konversi lahan tersebut. Oxfam sebagai lembaga nirlaba internasional yang ada di Indonesia dimana salah satu aktivitasnya bergerak untuk memerangi ketidakadilan, termasuk kepada penghasil pangan skala kecil, dengan cara melakukan advokasi. Dalam hal ini praktik advokasi yang dimaksud adalah representasi. Penelitian ini bermaksud untuk menjelaskan gambaran bagaimana proses perlindungan penghasil pangan skala kecil yang dilakukan oleh Oxfam Indonesia pada program pelayanan advokasi. Metode penelitian yang akan dilakukan pada penelitian adalah metode penelitian deskriptif. Laporan penelitian ini akan berisi penjelasan untuk memahami sebuah proses dan pemaknaanya secara lebih dalam melalui interpretasi. Permasalahan konversi lahan yang menimpa penghasil pangan skala kecil ini tidak luput dari sasaran organisasi sosial agar masyarakat dapat hidup dengan sejahtera. Oxfam berupaya memastikan para penghasil pangan skala kecil mampu memperoleh haknya dalam hal akses dan kontrol terhadap sumber daya, khususnya tanah, untuk memproduksi pangan. Upaya lain juga dilakukan melalui pelibatan kaum muda dan konsumen perkotaan, media dan juga para pembuat kebijakan.
\end{abstract}

Kata kunci : advokasi, penghasil pangan skala kecil, pelayanan sosial

\section{ABSTRACK}

Indonesia is an agricultural country with a land area of approximately 190.9 million ha. The problems faced by small-scale food producers at this time in the form of conversion of agricultural land into conversion to non-agricultural interests. The powerlessness of the small-scale food producers to maintain their agricultural land into the cause of the conversion of the land. Oxfam as an international non-profit organizations that exist in Indonesia, where one of the activities move to combat injustice, including the small-scale food producers, by doing advocacy. In this case advocacy practice in question is representation. This study intends to clarify the picture of how the process of protecting small-scale food producers conducted by Oxfam Indonesia on advocacy services program. Methods of research to be conducted on the research is descriptive research method. Land conversion issues affecting small-scale food producers have not missed the mark social organization so that people can live in peace. Oxfam seeks to ensure that small-scale food producers are able to obtain their rights in terms of access to and control over resources, particularly land, to produce food. 
Efforts have also been made through the involvement of youth and urban consumers, the media and policy makers.

Keywords: advocacy, small-scale food producers, social services

\section{PENDAHULUAN}

Pertambahan jumlah penduduk yang terus meningkat, dibarengi dengan pertumbuhan ekonomi dan industri, menimbulkan konversi lahan pertanian. Masalah yang dihadapi oleh penghasil pangan skala kecil saat ini berupa konversi lahan pertanian menjadi alih fungsi untuk kepentingan non-pertanian.

Ketidakberdayaan para penghasil pangan skala kecil untuk menjaga lahan pertanian yang mereka miliki menjadi penyebab terjadinya konversi lahan tersebut. Hanya karena diiming-imingi bahwa mereka akan mendapatkan ganti rugi lahan yang akan diberikan dalam jumlah besar, dengan mudah mereka melepas lahan untuk digunakan kegiatan non-pertanian. Rata-rata para petani hanya mengetahui bahwa lahan yang mereka gunakan untuk pertanian itu sebagai satusatunya sumber mata pencaharian bagi mereka. Padahal dengan produksi beras yang mereka hasilkan secara lebih jauh merupakan potensi sumber daya yang besar bagi negara.

Keterbatasan pengetahuan yang dimiliki oleh petani ini menjadi celah bagi para pengusaha untuk melakukan konversi lahan. Tidak hanya petani, kesadaran masyarakat akan pentingnya menjaga keutuhan pangan skala kecil pun masih sangat minim. Konversi lahan banyak terjadi di Jawa. Selama periode 1979 - 1999 tercatat seluas $625.459(38,43 \%)$ atau 31.273 ha/tahun lahan sawah di Jawa telah terkonversi (Isa, 2006).

Mengingat dampak yang ditimbulkan oleh adanya konversi lahan yang begitu luas, perlu kiranya ada upaya-upaya pengendaliannya. Berdasarkan penelitian yang dilakukan oleh Mukhtar Rosyid Harjono (2005) pengendalian konversi lahan pertanian merupakan sebuah sistem yang melibatkan peraturan dan pelakunya. Sehingga diperlukan adanya keterikatan misi antar instansi agar dapat mengintegrasikan berbagai kepentingan dalam rangka pengendalian lahan pertanian. Disamping itu juga perlu adanya sosialisasi pada masyarakat akan pentingnya menjaga kelestarian lahan pertanian demi ketahanan pangan.

Oxfam sebagai lembaga nirlaba internasional yang ada di Indonesia dimana salah satu aktivitasnya bergerak untuk memerangi ketidakadilan, termasuk kepada penghasil pangan skala kecil, dengan cara melakukan advokasi. Dalam hal ini praktik advokasi yang dimaksud adalah representasi. Kegiatan terkait orientasi tindakan dan aktivitas advokat dengan berbicara, menulis, atau bertindak bagi pihak lain, berkomunikasi atau pernyataan kepedulian terhadap klien.

Oxfam mempunyai perhatian besar terhadap realisasi hak atas pangan. Oxfam berupaya memastikan para penghasil pangan skala kecil, baik perempuan maupun laki-laki, mampu memperoleh haknya dalam hal akses dan kontrol terhadap sumber daya, khususnya tanah, untuk memproduksi pangan. Selain itu, upaya lain juga dilakukan melalui pelibatan kaum muda dan konsumen perkotaan, media dan juga para pembuat kebijakan untuk mengatasi masalah konversi lahan milik para penghasil pangan skala kecil.

Berbagai penelitian telah dilakukan sebelumnya terkait penghasil pangan skala kecil dan permasalahan lahan yang dihadapi. Diantaranya Anita Widhy Handari (2012) melakukan penelitian mengenai implementasi kebijakan perlindungan lahan pertanian pangan. Hasil penelitian mengemukakan bahwa implementasi kebijakan perlindungan lahan pertanian baru sampai pada proses identifikasi lahan. Penelitian ini juga mengetahui bahwa faktor-faktor yang 
mempengaruhi implementasi kebijakan menunjukkan hasil yang tidak signifikan. Melalui penelitian ini juga diperoleh alternatif strategi yang menjadi prioritas dalam perlindungan lahan pertanian berkelanjutan adalah dari aspek ekologi.

Penelitian lain yang dilakukan oleh S. Djuni Prihatin, Sunarru Samsi Hariadi, dan Mudiyono terkait ancaman ketahanan pangan rumah tangga petani. Hasilnya menyebutkan untuk mewujudkan terciptanya ketahanan rumah tangga petani, yaitu dengan mewajibkan pemerintah untuk semakin menunjukkan keberpihakannya bagi petani. Disatu sisi mendorong produksi pangan yang optimal sekaligus mengendalikan laju impor di bidang pangan, sehingga memberikan kesempatan kepada petani untuk dapat meningkatkan kesejahteraan bagi keluarga dan mendukung terciptanya ketahanan pangan nasional.

Berdasarkan kedua penelitian yang telah dikemukakan di atas, dapat diketahui bahwa penelitian tentang kebijakan perlindungan lahan penghasil pangan skala kecil dan ancaman ketahanan pangan rumah tangga petani. Namun, proses pelayanan advokasi pada penghasil pangan skala kecil belum diketahui melalui penelitian. Oleh karena itu, peneliti bermaksud untuk melakukan penelitian dengan tujuan mengetahui proses pelayanan advokasi yang dilakukan terhadap penghasil pangan skala kecil.

\section{HASIL DAN PEMBAHASAN}

\section{Masalah Pangan di Indonesia}

Indonesia adalah negara agraris dengan luas daratan kurang lebih 190,9 juta ha. Dari keseluruhan luasan tersebut, $37,1 \%$ telah dimanfaatkan untuk kegiatan budidaya, seperti sawah, pertanian lahan kering, perkebunan, ladang dan penggunaan lainnya, sedangkan $62,9 \%$ lainnya berupa hutan. Dengan adanya pertambahan jumlah penduduk yang terus meningkat, dibarengi dengan pertumbuhan ekonomi dan industri, menimbulkan konversi lahan pertanian. Konversi lahan adalah perubahan fungsi sebagian atau seluruh kawasan lahan dari fungsinya semula (seperti yang direncanakan) menjadi fungsi lain yang menjadi dampak negatif (masalah) terhadap lingkungan dan potensi lahan. Konversi lahan juga dapat diartikan sebagai perubahan untuk penggunaan lain disebabkan oleh faktor-faktor yang secara garis besar meliputi keperluan untuk memenuhi kebutuhan penduduk yang semakin bertambah jumlahnya dan meningkatnya tuntutan akan mutu kehidupan yang lebih baik (Rustiadi dan Reti, 2008 dalam MF. Anita Widhy Handary).

Inilah kenyataan yang sedang dihadapi pangan Indonesia saat ini. Produksi pangan, terutama pangan pokok seperti beras berkurang akibat konversi lahan. Persawahan sudah berubah wujud menjadi bangunan-bangunan kokoh untuk pabrik. Pola konversi lahan berdasarkan analisis perubahan penggunaan lahan, terjadi paling banyak di Jawa. Menurut Pasandaran (dalam MF. Anita Widhy Handary,2006), ada tiga faktor yang merupakan determinan konversi lahan, yaitu kelangkaan sumber daya lahan air, dinamika pembangunan, dan peningkatan jumlah penduduk. Dampak dari konversi lahan tidak hanya dirasakan oleh para pemilik lahan, tetapi dapat dirasakan secara meluas oleh seluruh lapisan masyarakat.

Menurut Notohadipawiro (dalam MF. Anita Widhy Handary 1991), lahan merupakan kesatuan berbagai sumber daya daratan yang saling berinteraksi membentuk suatu sistem struktural dan fungsional.

\section{Penghasil Pangan Skala Kecil}

Menurut UU RI No. 9 tahun 1995 tentang Industri kecil, maka batasan Industri kecil didefinisikan kegiatan ekonomi yang dilakukan oleh perseorangan atau rumah tangga maupun suatu badan, bertujuan untuk memproduksi barang ataupun jasa untuk diperniagakan secara komersial, yang mempunyai kekayaan bersih paling banyak Rp. 200 juta, dan mempunyai nilai penjualan per tahun sebesar Rp. 1 milyar atau kurang. Pangan menjadi salah satu bidang yang tidak luput dari industri kecil yang ada di Indonesia. 
Kenyataannya saat ini penghasil pangan skala kecil di Indonesia menghadapi masalah antara lain :

1. Kebutuhan pangan masyarakat lebih tinggi dari kapasitas produksi dalam negeri.

2. Pengurangan luasan lahan pertanian produktif akibat konversi penggunaannya untuk kepentingan non-pertanian.

3. Pola konsumsi yang masih sangat didominasi oleh beras, upaya diversifikasi pangan masih terkendala oleh keterbatasan pengetahuan dan keterjangkauan.

4. Pasokan pangan hingga tingkat rumah tangga sering terhambat sebagai akibat dari keterbatasan jaringan transportasi.

5. Beberapa produk pangan tidak tersedia sepanjang tahun karena siklus produksi alami jenis komoditas pangan yang dibudidayakan, fakor agroklimat, dan belum berkembangnya agroindustri untuk pengolahan/pengawetan.

6. Masih sering dijumpai produk pangan yang tidak memenuhi standar kesehatan pangan dan/atau sesuai dengan syarat kehalannya.

7. Belum semua rumah tangga secara ekonomi mampu memenuhi kebutuhan pangan pokoknya

8. Marjin keuntungan usaha tani tanaman pangan sangat kecil, sehingga sangat menghambat motivasi petani untuk meningkatkan produksinya.

Dalam uraian diatas disebutkan salah satu masalah yang dihadapi penghasil pangan skala kecil, yaitu semakin berkurangnya lahan untuk pertanian karena alih fungsi lahan yang digunakan demi kepentingan non-pertanian. Sektor industri kecil mempunyai peran penting dalam perekonomian baik daerah maupun nasional.
Lembaga Pelayanan Sosial

Permasalahan konversi lahan yang menimpa penghasil pangan skala kecil ini tidak luput dari sasaran organisasi sosial yang notabennya bergerak agar masyarakat dapat hidup dengan sejahtera. Lembaga pelayanan sosial atau Menurut Budhi Wibawa dkk :

Organisasi pelayanan sosial
merupakan organisasi formal yang
fungsi utamanya menyelenggarakan
pelayanan kesejahteraan sosial yang
ditujukan untuk memecahkan masalah
dan atau memenuhi kebutuhan
masyarakat.

Dengan kata lain, lembaga pelayanan sosial memiliki tujuan untuk melindungi masayarakat agar dapat tetap hidup dengan layak. Adanya lembaga pelayanan sosial adalah jawaban atas kondisi yang ada di masyarakat atau sebagai salah satu upaya yang dilakukan masyarakat secara mandiri atau pemerintah untuk menangani permasalahan yang terjadi.

Terdapat berbagai jenis pelayanan sosial yang ada hingga saat ini. Hal ini bergantung pada perubahan struktur kehidupan manusia dalam bermasyarakat. Dalam penyelenggaraannya, tentunya setiap organisasi sosial memiliki aktivitas yang berbeda-beda sesuai dengan tujuan yang ingin dicapai oleh masing-masing organisasi sosial.

\section{Pelayanan Advokasi Perlindungan Hasil Pangan Skala Kecil}

Menurut Zastrow (1982) advokasi adalah aktivitas memberikan pertolongan terhadap klien untuk mencapai layanan (service) yang mereka telah ditolak sebelumnya dan memberikan ekspansi terhadap layanan tersebut agar banyak orang yang terwadahi. Pada konteks perlindungan pangan skala kecil ini terdapat perundang-undangan yang menjadi dasar untuk melakukakn advokasi. Undang-Undang Nomor 41 Tahun 2009 Tentang Perlindungan Lahan Pertanian Pangan Berkelanjutan, yang didalamnya mengatur 
tentang asas, tujuan, ruang lingkup, perencanaan dan penetapan, pengembangan, penelitian, pemanfaatan, pembinaan, pengendalian, pengawasan, sistem informasi, perlindungan dan pemberdayaan petani, pembiayaan, sanksi administrasi, serta ketentuan pidana.

Dengan adanya undang-undang tersebut, sesuai definisi yang dikemukakan oleh Zastrow maka hak-hak penghasil pangan skala kecil yang saat ini dirampas guna kepentingan tertentu dapat diperjuangkan. Karena dampak yang ditimbulkan akibat konversi lahan pangan ini tidak hanya berpengaruh bagi petani saja, tetapi juga bagi masyarakat luas. Sebagaimana kita ketahui pangan merupakan kebutuhan pokok yang harus dipenuhi oleh manusia untuk bertahan hidup.

\section{Masalah Perlindungan Pangan Skala Kecil}

Sawah merupakan lahan penghasil pangan pokok yang dipandang sebagai sistem pertanian yang berkelanjutan. Hal ini dikarenakan ekosistem sawah yang stabil dan tingkat penggunaan air yang efisien. Dilakukannya konversi lahan pertanian sawah sama saja dengan mengganngu pelestarian lingkungan. Selain itu, konversi lahan juga akan mengganggu keseimbangan hubungan sistemik antara petani dengan lahannya. Sawah merupakan pengikat kelembagaan desa (Rustiadi dan Reti, 2008 MF. Anita Widhy Handary ).

\section{Budhi Wibhawa dkk (2010)}

berpendapat :

Secara tradisional masalah-masalah sosial ditangani melalui lembagalembaga kemasyarakatan, khususnya keluarga dan model-model usaha kesejahteraan sosial seperti lumbung desa, namun dengan pandangan bahwa sumber penyebab masalah sosial adalah perubahan sosial, dan dengn melihat perkembangan masalah sosial dewasa ini serta kemungkinannya di masa mendatang, maka lembaga- lembaga kemasyarakatan tersebut sudah mengalami pula pergeseran fungsi dan strukturnya sehingga tidak dapat lagi mengimbangi perubahan pada sub-sistem masyarakat yang lain.

Ditinjau dari fenomena yang terjadi, konversi lahan merupakan masalah sosial yang termasuk ke dalam kajian bidang ilmu kesejahteraan sosial. Perspektif pekerjaan sosial melihat tindakan yang dilakukan dalam konversi lahan pangan, khususnya pada petani yang terganggu keberfungsian sosialnya. Dimana rata-rata dari mereka adalah penduduk lokal yang menggarap sawah menjadi pekerjaan utama. Maka, dengan adanya konversi lahan menimbulkan efek domino bagi kehidupan para petani penghasil pangan lokal.

Peran Lembaga Pelayanan Sosial sebagai Advokad

Salah satu aktivitas profesional Pekerja Sosial adalah pelayanan Sosial. Pelayanan sosial merupakan jawaban terhadap tuntutan kebutuhan dan masalah yang dialami masyarakat sebagai akibat perubahan masyarakat itu sendiri. Dengan demikian bidang-bidang pelayanan sosial akan tergantung pada bagaimana Pekerja Sosial memandang dan mengidentifikasikan masalah-masalah sosial yang terjadi di dalam masyarakat (Budhi Wibhawa dkk,2010). Dalam praktiknya Pekerja Sosial terbagi ke dalam beberapa peran.

Peran Pekerja Sosial dalam kelompok menurut Budhi Wibhawa dkk (2010) :

1. Broker, yaitu semacam penghubung antara klien dengan pihak-pihak yang dapat membantunya

2. Mediator, yaitu Pekerja Sosial yang membantu menyelesaikan konflik pertikaian ataupun perselisihan anggota kelompok

3. Educator, yaitu sebagai guru, Pekerja Sosial memberikan informasi baru, model-model untuk membantu partisipan mempelajari keterampilan baru 
4. Fasilitator, yaitu sebagai orang yang akan mempermudah dan meringankan jalan partisipan

Sebuah lembaga pelayanan Sosial bisa bergerak dalam bidang advokasi atau dalam peran Pekerja Sosial yang telah disebutkan diatas adalah broker. Tidak menutup kemungkinan juga dalam satu lembaga pelayanan sosial terdiri dari beberapa peran Pekerja Sosial di dalamnya. Pada pelaksanaannya lembaga pelayanan sosial yang bertindak sebagai advokad bertujuan untuk memperjuangkan hak-hak yang seharusnya diperoleh oleh masyarakat, baik secara individu ataupun kelompok.

\section{Advokasi dalam Pekerjaan Sosial}

Pada sub-bab sebelumnya penulis telah menyebutkan definisi advokasi menurut Zastrow. Advokasi itu sendiri dalam Pekerjaan Sosial didefiniskan sebagai salah satu proses pemberian bantuan yang dilakukan oleh Pekerja Sosial dalam menangani ketidakberfungsian sosial yang dialami oleh klien. Menurut Barker (dalam Krist-Ashman) terdapat dua definisi tentang advokasi, yaitu:

1. Tindakan atau kegiatan yang secara langsung mewakili dan membela atau memperjuangkan (hak) orang lain.

2. Memperjuangkan hak-hak individu atau masyarakat melalui intervensi langsung atau melalui pemberdayaan.

\section{Pelayanan Kesejahteraan Sosial Masyarakat}

Friedlander (dalam Budhi Wibhawa dkk) mengemukakan beberapa jenis pelayanan sosial yang diusahakan melalui organisasi sosial yaitu:

1. Bantuan sosial (public assistance)

2. Asuransi sosial (social insurance)

3. Pelayanan kesejahteraan keluarga (family welfare services)

4. Pelayanan kesejahteraan anak (Child welfare services)
5. Pelayanan kesehatan dan pengobatan (Health and medical services)

6. Pelayanan kesejahteraan jiwa ( Mental hygine services)

7. Pelayanan koreksional (Correctional services)

8. Pelayanan kesejahteraan pemuda pengisian waktu luang (youth leissuretime services)

9. Pelayanan kesejahteraan bagi veteran (veteran services)

10. Pelayanan ketenagakerjaan (employment services)

11. Pelayanan bidang perumahan (housing services)

12. Pelayanan sosial internasional (international social services)

13. Pelayanan kesejahteraan sosial masyarakat (community social services)

Tujuan adanya pelayanan kesejahteraan sosial bagi masyarakat yang diselenggarakan oleh organisasi sosial adalah untuk membantu masyarakat agar dapat kehidupan yang layak. Menurut Budhi Wibhawa dkk (2010) konsep kesejahteraan sosial sebagai suatu sistem pelayanan sosial dapat dipahami, sebagai berikut :

1. Konsep pelayanan sosial (bidang praktik Pekerjaan Sosial) mencakup aktivitas yang sangat luas, mulai dari perundangundangan sosial sampai kepada tindakan langsung pemberian bantuan.

2. Konsep 'Kesejahteraan Sosial' berbeda dengan 'kesejahteraan'. Terpenuhinya kebutuhan sosial (kesejahteraan sosial sebagai suatu keadaan) menjadi dasr bagi terciptanya 'kesejahteraan' (sebagai keadaan yang baik dalam semua aspek kehidupan manusia).

Pada tingkat masyarakat, kesejahteraan sosial berarti terdapatnya ketertiban sosial (social order) yang lebih baik. 


\section{SIMPULAN}

Oxfam berupaya memastikan para penghasil pangan skala kecil mampu memperoleh haknya dalam hal akses dan kontrol terhadap sumber daya, khususnya tanah, untuk memproduksi pangan melalui pelayanan advokasi. Pada pelaksanaannya lembaga pelayanan sosial yang bertindak sebagai advokad bertujuan untuk memperjuangkan hak-hak yang seharusnya diperoleh oleh masyarakat, baik secara individu ataupun kelompok. Advokasi dilakukan melalui pelibatan kaum muda dan konsumen perkotaan, media dan juga para pembuat kebijakan. Hingga saat ini tidak semua orang memiliki kesadaran akan pentingnya pemenuhan hak bagi para penghasil pangan skala kecil.

\section{REKOMENDASI}

Beberapa rekomendasi dalam penanganan pelayanan advokasi penghasil pangan skala kecil meliputi :

1. Perlu adanya kerja sama yang baik antara para stakeholder terkait.

2. Pentingnya pemenuhan hak penghasil pangan skala kecil harus terus dipromosikan.

3. Diadakannya pengawasan terhadap pelaksanaan kebijakan tentang penghasil pangan skala kecil.

\section{DAFTAR PUSTAKA}

Bungin, Burhan. 2011. Penelitian Kualitatif. Jakarta: Kencana

Riduwan. 2013. Belajar Mudah Penelitian. Bandung: Alfabeta

Wibhawa, Budhi, dkk. 2010. Dasar-dasar Pekerjaan Sosial. Bandung: Widya Padjadjaran

Gabriel Abdi Susanto. “Ayo Dukung Pangan Lokal!".

Melalui http://health.liputan6.com/read/7229 90.html. [07/03/15]

Republika .co.id. "Karawang Terancam Kehilangan 300 Ton Gabah". Melalui http://www.republika.co.id/berita/nasi onal/jawa-barat-nasiona.html [07/03/15]

Widhi Handari, Anita, MF. 2012. Implementasi Kebijakan Perlindungan Lahan Pertanian Pangan Berkelanjutan di Kabupaten Magelang. Tesis. Sarjana S-2 Program Studi Ilmu Lingkungan, Universitas Diponegoro, Semarang. 